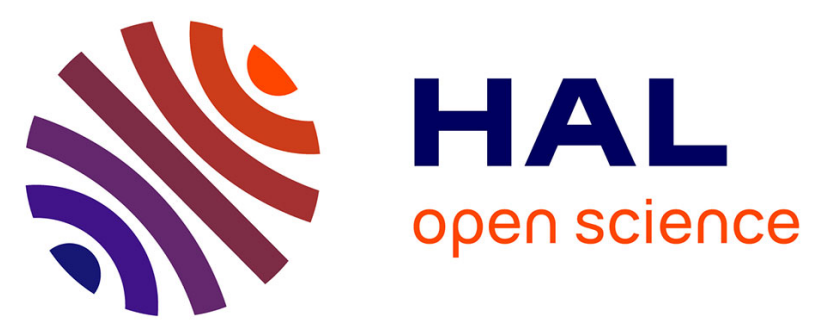

\title{
A major hydrobiological change in Dasht-e Arjan Wetland (southwestern Iran) during the late glacial - early Holocene transition revealed by subfossil chironomids
}

\author{
Cyril Aubert, Morteza Djamali, Matthew Jones, Hamid Lahijani, Nick \\ Marriner, Abdolmajid Naderi-Beni, Arash Sharifi, Philippe Ponel, Emmanuel \\ Gandouin
}

\section{- To cite this version:}

Cyril Aubert, Morteza Djamali, Matthew Jones, Hamid Lahijani, Nick Marriner, et al.. A major hydrobiological change in Dasht-e Arjan Wetland (southwestern Iran) during the late glacial-early Holocene transition revealed by subfossil chironomids. Canadian journal of earth sciences, 2019, 56 (8), pp.848-856. 10.1139/cjes-2018-0256 . hal-02197624

\section{HAL Id: hal-02197624 \\ https://hal-amu.archives-ouvertes.fr/hal-02197624}

Submitted on 30 Jul 2019

HAL is a multi-disciplinary open access archive for the deposit and dissemination of scientific research documents, whether they are published or not. The documents may come from teaching and research institutions in France or abroad, or from public or private research centers.
L'archive ouverte pluridisciplinaire HAL, est destinée au dépôt et à la diffusion de documents scientifiques de niveau recherche, publiés ou non, émanant des établissements d'enseignement et de recherche français ou étrangers, des laboratoires publics ou privés. 


\title{
A major hydrobiological change in Dasht-e Arjan Wetland (southwestern Iran) during the late glacial - early Holocene transition revealed by subfossil chironomids
}

\author{
Cyril Aubert, Morteza Djamali, Matthew Jones, Hamid Lahijani, Nick Marriner, \\ Abdolmajid Naderi-Beni, Arash Sharifi, Philippe Ponel, and Emmanuel Gandouin
}

\begin{abstract}
The late glacial - early Holocene transition is a key period in the earth's history. However, although this transition is well studied in Europe, it is not well constrained in the Middle East and palaeohydrological records with robust chronologies remain scarce from this region. Here we present an interesting hydrobiological record showing a major environmental change occurring in the Dasht-e Arjan Wetland (southwestern Iran, near to Persepolis) during the late glacial - early Holocene transition (ca. 11650 years cal BP). We use subfossil chironomids (Insecta: Diptera) as a proxy for hydrological changes and to reconstruct lake-level fluctuations. The Arjan wetland was a deep lake during the Younger Dryas marked by a dominance of Chironomus plumosus/anthracinus-type, taxa adapted to anoxic conditions of deep waters. At the beginning of the Holocene, a drastic decrease (more than $80 \%$ to less than $10 \%$ ) of Chironomus plumosus/anthracinus-type, combined with diversification of littoral taxa such as Polypedilum nubeculosum-type, Dicrotendipes nervosus-type, and Glyptotendipes pallens-type, suggests a lake-level decrease and a more vegetalized aquatic environment. We compare and contrast the chironomid record of Arjan with a similar record from northwestern Iran. The palaeoclimatic significance of the record, at a local and regional scale, is subsequently discussed. The increase in Northern Hemisphere temperatures, inferred by geochemical data from NGRIP, at the beginning of the Holocene best explains the change from the Younger Dryas highstand to early Holocene lowstand conditions in the Dasht-e Arjan wetland. However, a contribution of the meltwater inflow from small local glaciers in the catchment basin is not excluded.
\end{abstract}

Key words: Younger Dryas, climate change, Karst, lake-level change, Zagros.

Résumé : La transition tardiglaciaire - Holocène précoce représente une période clé de l'histoire de la terre. Si cette transition est bien étudiée en Europe, ce n'est toutefois pas le cas au Moyen-Orient, et les profils paléohydrologiques associés à des chronologies robustes demeurent rares pour cette région. Nous présentons un profil hydrobiologique intéressant qui montre un important changement environnemental s'étant produit dans la zone humide de Dasht-e Arjan (sud-ouest de l'Iran, près de Persépolis) durant la transition tardiglaciaire-Holocène précoce (vers 11650 ans cal BP). Nous utilisons des subfossiles de chironomidés (insectes : diptères) comme indicateurs de changements hydrologiques et pour reconstituer les fluctuations du niveau de lacs. Le milieu humide d'Arjan était un lac profond durant le Dryas récent, caractérisé par une prépondérance de taxons de type Chironomus plumosus/anthracinus adaptés aux conditions anoxiques des eaux profondes. Une baisse drastique (de plus de 80 \% à moins de $10 \%$ ) de ces taxons au début de l'Holocène, combinée à la diversification de taxons littoraux de types Polypedilum nubeculosum, Dicrotendipes nervosus et Glyptotendipes pallens, indiquerait une baisse du niveau du lac et un milieu aquatique plus végétalisé. Nous comparons le profil des chironomidés d'Arjan à un profil semblable du nord-ouest de l'Iran. La signification paléoclimatique du profil, aux échelles locales et régionales, est ensuite abordée. L'augmentation des températures dans l'hémisphère nord au début de l'Holocène, inférée à partir de données géochimiques du NGRIP, est ce qui explique le mieux le passage de conditions de haut niveau du Dryas récent aux conditions de bas niveau de l'Holocène précoce dans la zone humide de Dasht-e Arjan. Un effet de l'apport d'eau de fonte de petits glaciers locaux dans le bassin versant n'est toutefois pas exclu. [Traduit par la Rédaction]

Mots-clés : Dryas récent, changement climatique, karst, changement du niveau des lacs, Zagros.

Received 4 October 2018. Accepted 20 January 2019.

C. Aubert, P. Ponel, and E. Gandouin. IMBE, CNRS, IRD, Aix-Marseille Université, Avignon Université, Aix en Provence, France. M. Djamali. IMBE, CNRS, IRD, Aix-Marseille Université, Avignon Université, Aix en Provence, France; INIOAS (Iranian National Institute for Oceanography and Atmospheric Sciences), No. 3, Etemad Zadeh St., Fatemi Ave., Tehran, Iran, 1411813389, 14155-4781.

M. Jones. School of Geography, University of Nottingham, University Park, Nottingham. NG7 2RD, U.K.

H. Lahijani and A. Naderi-Beni. INIOAS (Iranian National Institute for Oceanography and Atmospheric Sciences), No. 3, Etemad Zadeh St., Fatemi Ave., Tehran, Iran, 1411813389, 14155-4781.

N. Marriner. Laboratoire de Chrono-Environnement, CNRS, Besançon, France.

A. Sharifi. Halophytes and C4 Plants Research Laboratory, Department of Plant Science, School of Biology, University of Tehran, Tehran, Iran.

Corresponding author: Cyril Aubert (email: cyril.aubert@imbe.fr). 


\section{Introduction}

The late Pleistocene to early Holocene transition marks the final part of the "Last Glacial - Interglacial Transition" or "Last Termination" (Lowe and Walker 1997; Hoek et al. 2008). It is a key event in the earth's history characterized by a series of climatic changes of high magnitude that provide the possibility to investigate the mechanisms responsible for abrupt climatic changes (Hoek et al. 2008). In the North Atlantic region, a detailed spatiotemporal framework is now available for the patterns of hydroclimatic and biotic changes during this transition (e.g., Ammann et al. 2000; Rasmussen et al. 2006). The biotic responses to late glacial - early Holocene climatic changes display many spatial discrepancies highlighting the important role of local ecological conditions such as lake topography and the composition of aquatic macrophyte communities (Engels and Cwynar 2011). In the low temperate to subtropical latitudes of southwestern Asia, the late glacial hydroclimatic changes are still poorly understood compared to Europe and the Mediterranean. In the Middle East, for instance, the more complex interactions between climatic systems can potentially cause more multifaceted responses of biomes to hydroclimatic variations (Djamali et al. 2010). Furthermore, this is a key period during which nomadic hunter-gatherers sedenterized to form the first farming communities (Blockley and Pinhasi 2011; Willcox 2012). In this regard, the Zagros-Taurus Mountains in western Iran and southeastern Turkey is a key region in understanding the Neolithisation process (Matthews and Fazeli 2013). A recent discovery of the cultivation of wild cereals in the foothills of the Zagros Mountains in Iran (Riehl et al. 2013), at the very onset of the Holocene, suggests that this area should also be considered as one of the earliest centers for cereal and pulse domestication in the Middle East. In addition, the study of ancient DNA of human remains dating to Early Holocene suggests that the Zagros Mountains constitute the major center of eastward expansion of early farming communities (Broushaki et al. 2016). Unraveling the hydroclimatic changes associated with these events is thus important in understanding and in contextualizing the possible environmental changes responsible for the early Neolithisation of the region.

In the Middle East, although palaeohydrological records are available from northwestern Zagros, Eastern Anatolia, Caucasus, and the Talesh Mountains (e.g., Stevens et al. 2006; Sharifi et al. 2015; Aubert et al. 2017), no high-resolution record is available from the central-southern Zagros for the late glacial - early Holocene transition. The present study provides a hydrological record for this transition in the southern Zagros based on lacustrine deposits of the Dasht-e Arjan wetland. Chironomid head capsules, which have been demonstrated to be good palaeotemperature and palaeosalinity indicators (Heiri et al. 2011; Eggermont et al. 2006; Zhang et al. 2007), are also powerful proxies to reconstruct lake-level fluctuations (Eggermont et al. 2007). Recently, they have further been suggested as a promising proxy to reconstruct changes in precipitation seasonality in the semiarid region of the Middle East (Aubert et al. 2017). We place the new Arjan record in a regional context. We compare and contrast it with hydroclimatic changes of central Asia and eastern Mediterranean to further our regional understanding of ecosystem responses to this key climatic transition.

\section{Materials and methods}

\section{Study area}

Very little information is available from the wetland of Dasht-e Arjan (Plain of Arjan). The wetland $\left(29^{\circ} 36^{\prime} 38^{\prime \prime} \mathrm{N}, 51^{\circ} 59^{\prime} 04^{\prime \prime} \mathrm{E}\right.$, $1984 \mathrm{~m}$ asl) (Fig. 1) is located ca. $50 \mathrm{~km}$ to the west of Shiraz. It is a relatively large, moderately saline lake located near Lake Parishan with which it forms a Wetland of International Importance (Ramsar Site No. 37; https://www.ramsar.org). The climate of Shiraz (1540 $\mathrm{m}$ asl) is of continental Mediterranean-type (Djamali et al.
2011) with most of the precipitation falling during the winter months (Fig. 1C). Apart from the direct precipitation in its catchment basin, a major source for the Dasht-e Arjan wetland is the Arjan spring, which has a discharge rate fluctuating between 750 and $100 \mathrm{~L} / \mathrm{s}$ (Milanovic and Aghili 1990).

Although located within the Zagros Fold Belt, the Dasht-e Arjan region is situated in a local extensional tectonic setting that has created a subsiding sedimentary basin. The subsidence is controlled by the activity of two normal faults called the West Arjan Fault $\left(45^{\circ} \mathrm{N}, 78^{\circ} \mathrm{SE}\right)$ and the East Arjan Fault $\left(55^{\circ} \mathrm{N}, 70^{\circ} \mathrm{NW}\right)$ that have created the $100-500 \mathrm{~m}$ high and $\sim 10 \mathrm{~km}$ long southwestnortheast trended almost vertical cliffs composed mainly of Oligocene-Miocene Asmari limestone formation to the west and east of the wetland (Fig. 1B) (Seyrafian et al. 2011). Hydrogeologically, the Dasht-e Arjan wetland seems to be located in a "polje" (a flat karstic plain) whose waters are evacuated through a "ponor" (an opening in the bottom of a polje) of 10-15 m diameter into a karstic subterraneous system during highstands with possible hydrological connection to the Kazerun (Lake Parishan) basin (Milanovic and Aghili 1990).

\section{Coring, lithostratigraphy, and radiocarbon dating}

Coring was performed using a Cobra vibracorer, allowing the gathering of 10 successive core sections of $1 \mathrm{~m}$ length and $5 \mathrm{~cm}$ width from the southeastern corner of the lake $\left(29^{\circ} 35^{\prime} 33^{\prime \prime} \mathrm{N}\right.$, $51^{\circ} 59^{\prime} 03^{\prime \prime} \mathrm{E}, 1992 \mathrm{~m}$ asl) near the location of the "ponor" (Fig. 1B). The maximum depth attained was $960 \mathrm{~cm}$. The lithostratigraphy comprises three major units: (1) a basal unit dominated by calcareous clayey mud with traces of pedogenesis, (2) a middle section dominated by bioclastic calcareous mud, and (3) the upper unit dominated by organic-rich calcareous mud (Fig. 2, upper right). Six samples composed of bulk (peat and gyttja) and plant remains (fibers) were AMS radiocarbon dated at the Poznan Radiocarbon Laboratory (Table 1). The radiocarbon ages were calibrated using an Intcal13 calibration curve (Reimer et al. 2013) in the Clam package (Blaauw 2010) run in $\mathrm{R}$ software version 3.2.2 ( $\mathrm{R}$ Core Team 2012). The age-depth model is based on linear interpolation taking into account the probability distribution of the calibrated ages (Fig. 2). Two radiocarbon ages were excluded from the age-depth model (sample Poz-Arj478 at $478 \mathrm{~cm}$ and sample Poz-Arj756 at $756 \mathrm{~cm}$ depth) (Table 1). These two samples are outliers. The first sample is too old, possibly because of the old carbon found in the bulk sediment composed of calcareous mud, a sediment composition that tends to yield "older" ages (Table 1). The second sample is too young, most probably because it is composed of root and rootlets penetrating into old sediment from the much younger plants. The palustrine sedimentary facies which incorporates this sample display abundant root traces, corroborating this assumption (Fig. 2). A recent publication by Djamali et al. (2018) has shown that similar age inversions (too young ages) have also been reported from a palustrine carbonate facies in the western Persepolis basin. We have retained the ages provided by the samples Poz-Arj503, Poz-Arj614, and Poz-Arj671 because they are composed of in situ organic matter (gyttja to very fine grained peat) formed within the aquatic environments through biological processes. All carbonate content was removed through a chemical treatment at the radiocarbon laboratory of Poznan (T. Goslar, personal communication) diminishing the possible contamination by old carbon originating from geological formations. We consider that the age Poz-Arj614 giving a 2- $\sigma$ range age of $11631-12060$ years cal BP is a very reliable age and marks the second part of the Younger Dryas (YD), just before the onset of the Holocene. This age range is also displayed in the chironomid diagram of Fig. 3 (see Discussion).

\section{Chironomid analysis}

Sixteen sediment samples weighing between 40 and $90 \mathrm{~g}$ were analyzed for chironomids every $5 \mathrm{~cm}$ along the fossiliferous interval of $630-550 \mathrm{~cm}$. The laboratory methods used for extraction 
Fig. 1. (A) Location of the Dasht-e Arjan wetland and Lake Neor in the Iranian plateau. (B) The fault system controlling the subsidence of the Arjan basin with the position of the coring site. (C) Climate diagram of Shiraz. (D) Dasht-e Arjan during a lowstand with the position of coring site (Source: Google Earth; Landsat/Copernicus (B dating to December 1987) and CNES/Airbus (C dating to December 2016)). [Color online.]
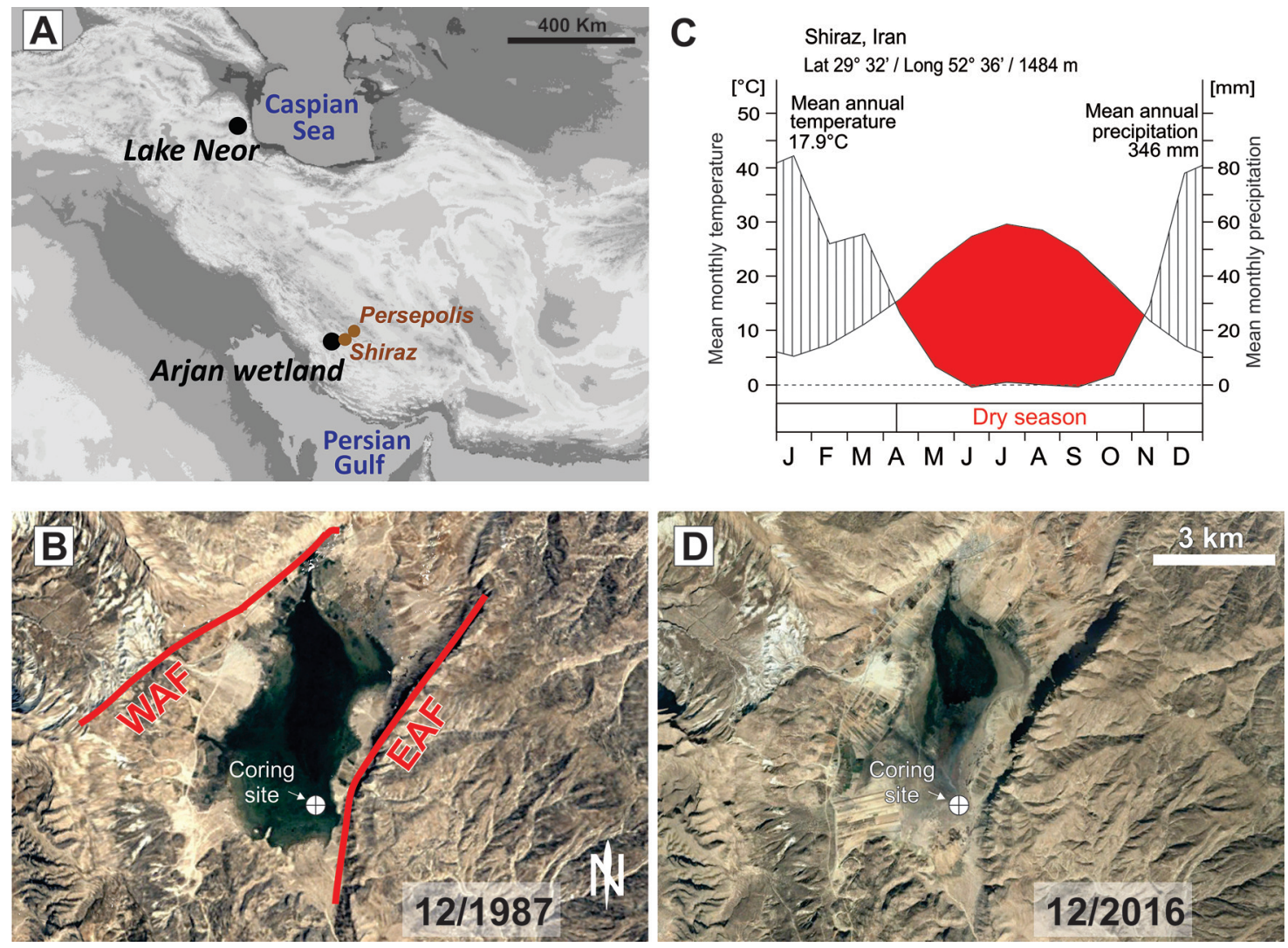

and identification of the chironomid subfossil head capsules are described in Gandouin et al. (2005). To summarize, the extraction consisted of $\mathrm{KOH}$ deflocculation, water-washing over a $100 \mu \mathrm{m}$ sieve, and oil flotation. A minimum of 50 head capsules per sample is required to provide statistically significant estimates of ecological conditions (Heiri and Lotter 2001). Identification criteria of head capsules are based on a Palearctic dichotomous key developed by Brooks et al. (2007). The chironomid abundance diagram was created using C2 software version 1.7.2 (Juggins 2007).

\section{Multivariate analyses of subfossil chironomid data}

A constrained sum-of-squares cluster analysis (CONISS) for percentage data was performed with $\mathrm{R}$ version 3.2.2 and the package "rioja" (Juggins 2017) to highlight major changes in chironomid assemblage composition throughout the stratigraphy (Grimm 1987). Principal component analysis (PCA) (Fig. 3) was performed on a data percentage matrix of nine taxa for 16 samples. The PCA was carried out with "ade4" and "vegan" packages in R software ( $R$ Core Team 2012). Beforehand, data were square-root-transformed with the aim of stabilizing the variance. Rare taxa (present in only one sample or with a relative abundance always $<5 \%$ ) were excluded from analyses.

\section{Results and interpretation}

For the chironomid analysis, only the section between 630 and $550 \mathrm{~cm}$ was used because it corresponds to the late glacial - early Holocene transition and presents almost the only interval with sufficient chironomid head capsules for statistical analyses. Interestingly, this sequence of $0.80 \mathrm{~m}$ corresponds to the end of the $\mathrm{YD}$ and the onset of the Holocene (6.30-5.50 m, $12380-10103$ years cal BP) (Fig. 2). Figure 3 presents a simplified diagram of chironomid relative abundances. CONISS analysis revealed three faunal assemblage

zones that we designate as Ach1: 630-605 cm (12 380 - 11650 years cal BP), Ach2: $605-563 \mathrm{~cm}(\sim 11650-10470$ years cal BP), and Ach3: 563-555 cm (10 470 - 10100 years cal BP). To the right of the chironomid diagram, percentage variations of a selection of pollen taxa have also been presented based on a recently published pollen diagram from the same study core (Hosseini et al. 2017).

\section{Ach1: 630-605 cm (12 380 - 11650 years cal BP)}

This zone is dominated by Chironomus plumosus/anthracinus-type and significant presence of Psectrocladius psilopterus-type (Fig. 3). Together, these two chironomid taxa constitute up to $90 \%$ of the chironomid assemblage (Fig. 3). PCA scores for these chironomid taxa and the samples containing them are both positioned on the positive side of PCA axis 1 between 0.5 and 1 (Fig. 4).

The Ach1 upper boundary closely mirrors the ARJp1 pollen assemblage zone (Fig. 3, right panel). This pollen zone is characterized by the dominance of pollen produced by very dry steppe plants (Amaranthaceae, Artemisia), low values of grasses (Poaceae), and the total absence of trees. Only towards its end do aquatic plants (Cyperaceae) and algae increase (Botryococcus and Pediastrum).

\section{Ach2: $605-563 \mathrm{~cm}$ ( $\sim 11,650$ - 10470 years cal BP)}

A remarkable faunal change occurs in this zone with a drastic reduction in Chironomus plumosus/anthracinus-type (Fig. 3) and, to a lesser extent, in Psectrocladius psilopterus-type percentages (from $80 \%-90 \%$ to below $10 \%$ for the latter taxa). By contrast, other taxa such as Polypedilum nubeculosum-type, Dicrotendipes nervosus-type, and Glyptotendipes pallens-type previously absent or in low abundances in the record become the dominant chironomid assemblages. Procladius spp. percentages also increase in this zone. PCA axis 1 scores follow the same trend as for Chironomus plumosus/ 
Fig. 2. Lithostratigraphic log and age-depth model for the whole core (upper right) with a detailed focus on the studied section from the Dasht-e Arjan wetland. The chironomid record presented here corresponds to the depths of 630-550 cm (12 $000-11200$ years cal BP). [Color online.]

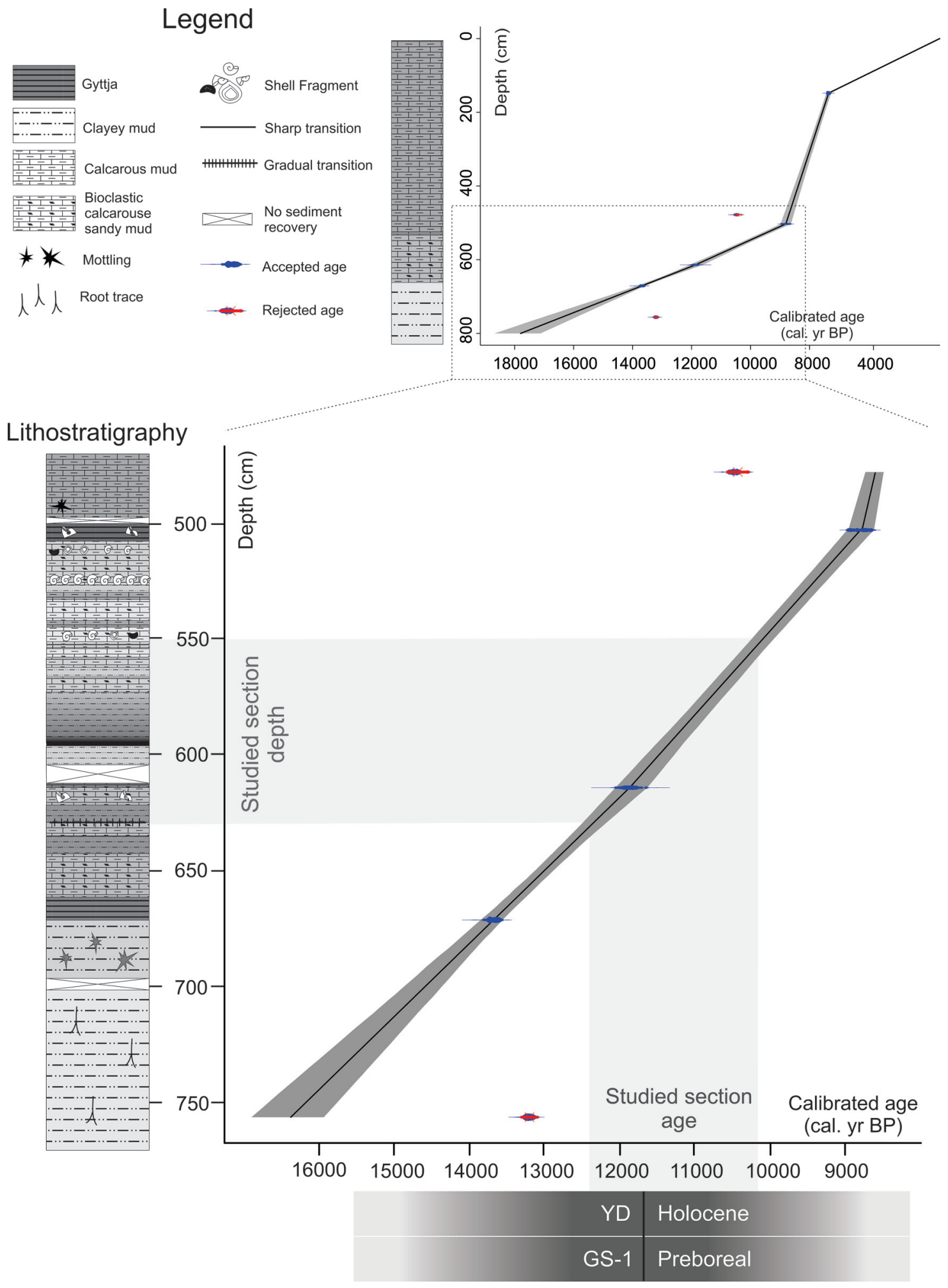

anthracinus-type and decrease markedly to around -1 during most of the upper part of the zone (see Fig. 3).

The Ach2 chironomid zone mostly correlates with the ARJp2 pollen assemblage zone, characterized by a sudden drop and then low values of Amaranthaceae and the dominance of grasses and semicontinuous presence of aquatic plants (Cyperaceae and Sparganium-type) and algae (Botryococcus and Pediastrum). Tree pollen appears in the diagram although with low values. A treeless grass-dominated steppe with moderately developed aquatic vegetation is inferred (Hosseini et al. 2017). 
Table 1. ${ }^{14} \mathrm{C}$ ages obtained and the type of corresponding material (Lake Arjan).

\begin{tabular}{llllc}
\hline $\begin{array}{l}\text { Laboratory } \\
\text { code }\end{array}$ & $\begin{array}{l}\text { Depth } \\
(\mathrm{cm})\end{array}$ & Material & $\begin{array}{l}\text { Age } \\
\left.\text { (years BP }\left({ }^{14} \mathrm{C}\right)\right)\end{array}$ & $\begin{array}{l}\text { Age (years cal BP } \\
(2-\sigma \text { interval) }\end{array}$ \\
\hline Poz-Arj148 & 148 & Organic mud & $6430 \pm 50$ & $7356(7274-7429)$ \\
Poz-Arj478 & 478 & Calcareous mud (bulk) & $9280 \pm 50$ & $10455(10287-10612)$ \\
Poz-Arj503 & 503 & Gyttja (bulk) & $7940 \pm 50$ & $10715(10573-10844)$ \\
Poz-Arj614 & 614 & Gyttja (bulk) & $10180 \pm 50$ & $11869(11631-12060)$ \\
Poz-Arj671 & 671 & Gyttja (bulk) & $11880 \pm 60$ & $12408(12255-12536)$ \\
Poz-Arj756 & 756 & Plant remains & $11370 \pm 60$ & $13212(13099-13332)$ \\
\hline
\end{tabular}

Note: Calibrated ages are reported with 2- $\sigma$ ranges. Excluded ages are marked in italics.

Fig. 3. Synthetic subfossil chironomid diagram from the Lake Arjan record (left) compared to pollen records for the same section of the same core (see Hosseini et al. 2017 for a detailed pollen diagram). The zonation pollen diagram was made visually. Profundal taxa inhabit profundal zones of the lake. Littoral taxa inhabit littorals margins of the lake. Other taxa are indifferent to depth or there are no documented ecological affinities. [Color online.]

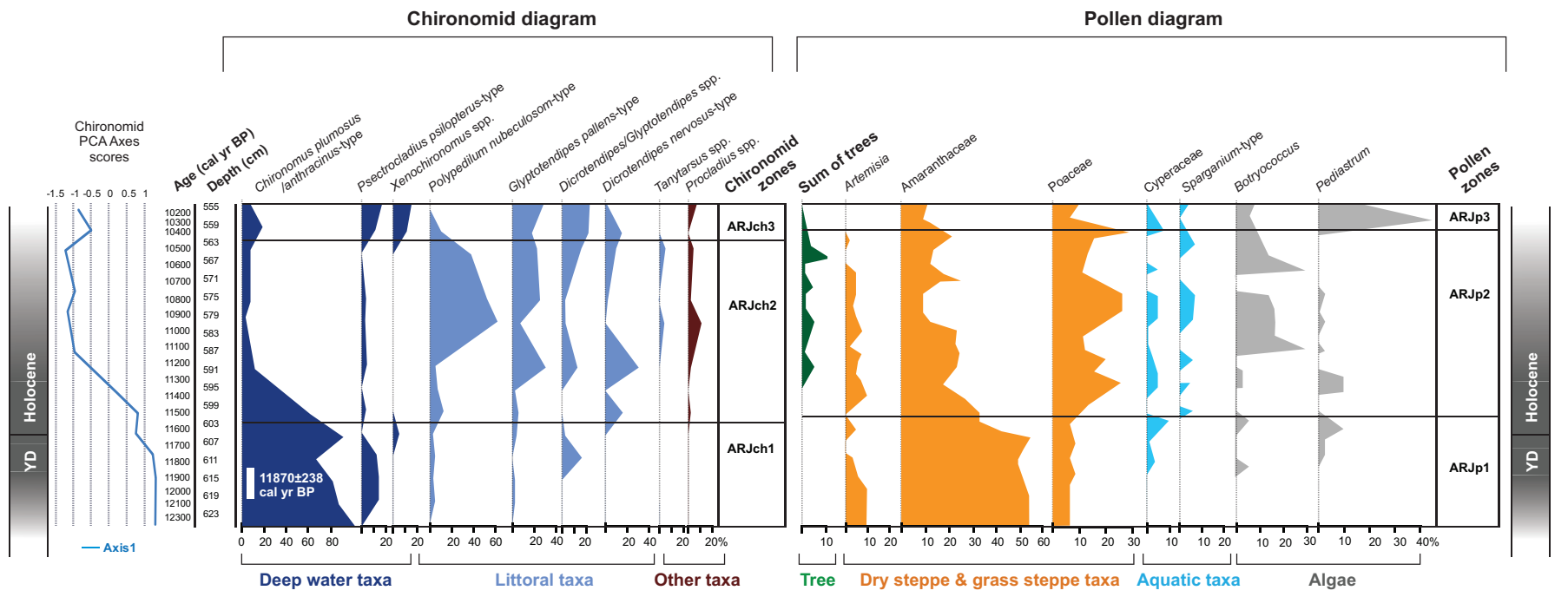

Fig. 4. Scatterplots for PCA scores of chironomid assemblages in the late glacial - early Holocene transition sediments of the Dasht-e Arjan wetland core showing the variable factor map of (A) PCA and contribution of different variables (taxa) to (B) axis 1 and (C) axis 2 . [Color online.]

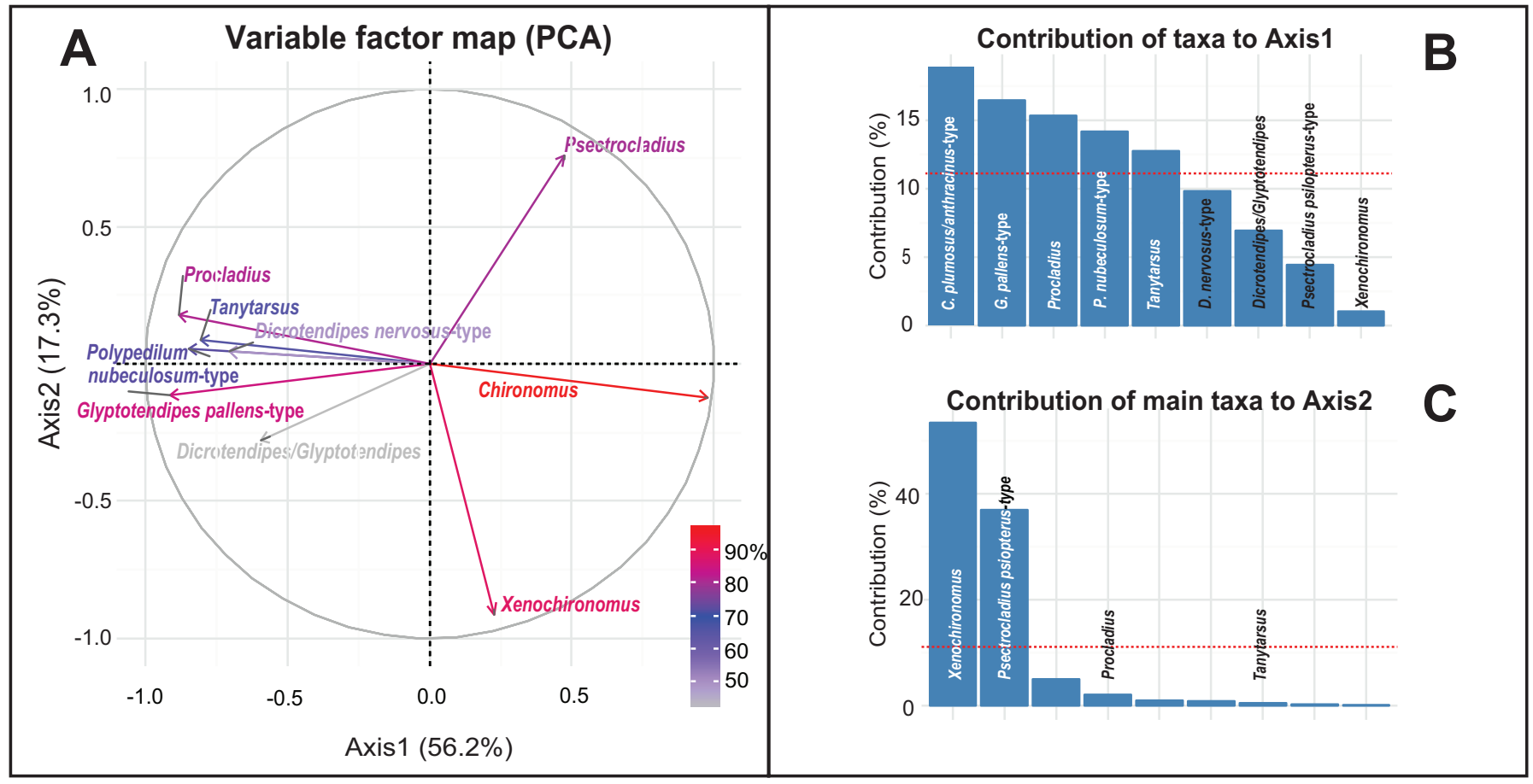


Fig. 5. Comparison of the abundance of the sum of the deepwater chironomid taxa between Lake Arjan and Lake Neor (Aubert et al. 2017) compared to temperature variations in Greenland (NGRIP record: North Greenland Ice Core Project members (2004) and aeolian activity in Lake Neor (Sharifi et al. 2015)). [Color online.]

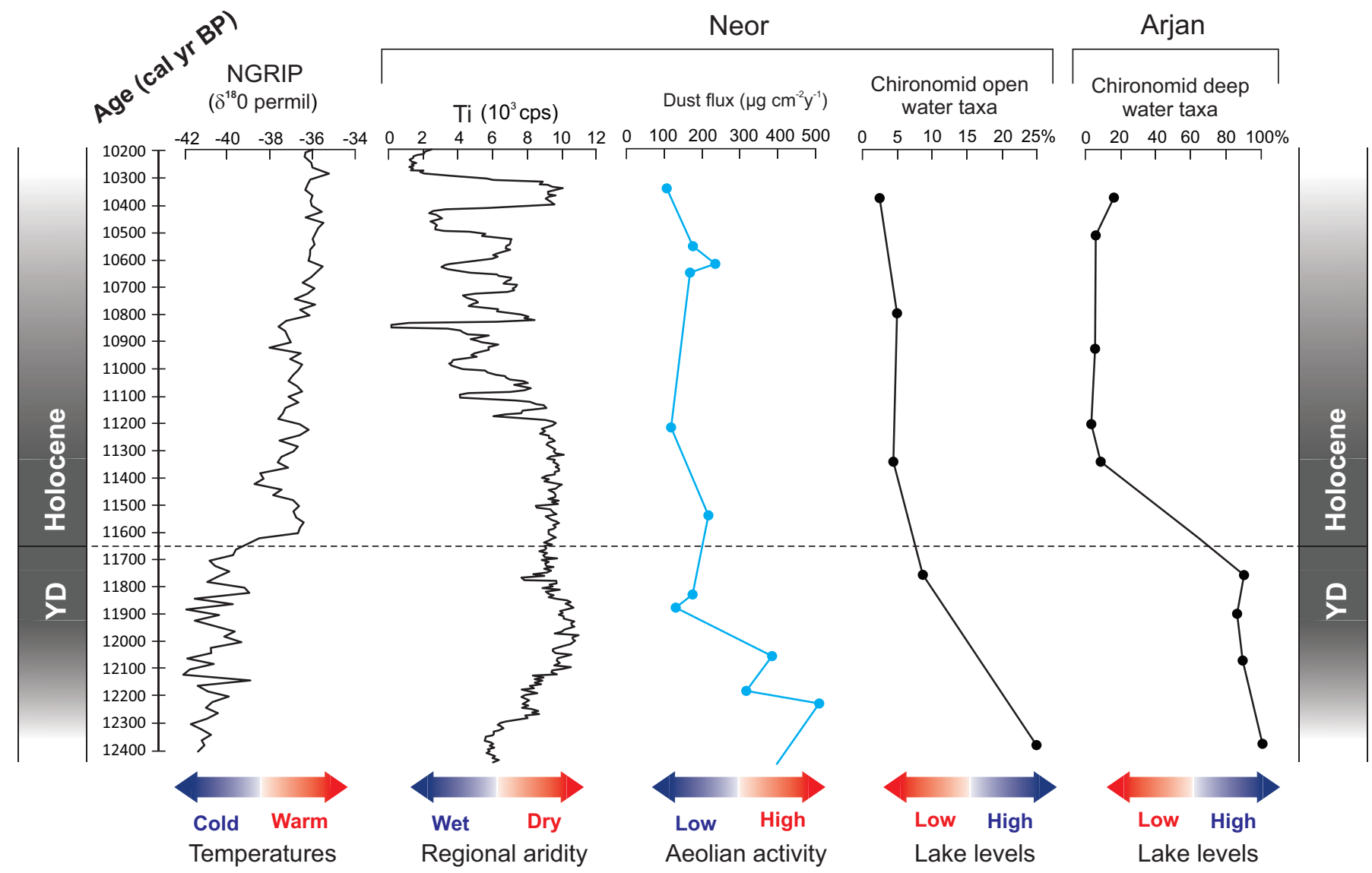

Ach3: 563-555 cm (10 470 - 10100 years cal BP)

In this zone, a slight rise of Chironomus plumosus/anthracinus-type and Psectrocladius psilopterus-type and a decrease of Polypedilum nubeculosum-type are observed (Fig. 3). Other littoral taxa such as Dicrotendipes nervosus-type and Glyptotendipes pallens-type are also present. Furthermore, we note the emergence of Xenochironomus spp. from $565 \mathrm{~cm}$. In the Ach 3 zone, PCA axis 1 scores increase slightly but remain negative $(-0.5)$ at the top of the sequence (Fig. 3 ).

The Ach3 chironomid zone correlates with the ARJp3 pollen assemblage zone in which grass pollen abundances decrease, while Pediastrum shows a peak. At the regional scale, a dry mountain steppe vegetation and nutrient-rich mesotrophic conditions are inferred (based on Pediastrum).

\section{Statistically based ecological groups of subfossil chironomids}

PCA axis 1 (56.2\% of the total variance) opposes Chironomus plumosus/anthracinus-type on the positive side (Fig. 4) to Glyptotendipes pallens-type, Procladius spp., Polypedilum nubeculosum-type, Tanytarsus spp., and Dicrotendipes nervosus-type on the negative side. PCA axis $2(17.3 \%$ of the total variance) is characterized by a segregation between Xenochironomus spp. and Psectrocladius psilopterus-type.

\section{Discussion}

\section{Chironomids as bathymetric bioindicators}

PCA axis 1 clearly shows an opposition between Chironomus plumosus/anthracinus-type mostly confined to the profundal zone of lakes (Brooks et al. 2007) against the inhabitants of the littoral zone and shallower water environments such as Glyptotendipes pallens-type and Polypedilum nubeculosum-type. Glyptotendipes pallens- type is most often associated with aquatic macrophytes (Brooks et al. 2007; Langdon et al. 2010). In fact, Polypedilum nubeculosumtype indicates relatively clear waters with variable macrophyte density and (or) high plant species richness (Langdon et al. 2010). Chironomus plumosus/anthracinus-type is often associated with loose and fine-grained sediments such as mud and silt (Henrikson et al. 1982; Brodin 1986). Among the Chironomus genera, many species are also adapted to live and survive in deep waters and possibly hypoxic or anoxic conditions by producing a large amount of hemoglobin (Brooks et al. 2007). It is well established elsewhere that chironomids are influenced by lake bathymetry (Verneaux and Aleya 1998) and several transfer functions have been successfully developed to reconstruct Holocene lake-level changes in Scandinavia (Luoto et al. 2018), in Canada (Barley et al. 2006), and in China (Chang et al. 2017;Wang et al. 2018).

Hence, PCA axis 1 (Fig. 4) may represent a bathymetric gradient with more positive scores indicating higher lake levels, whereas more negative scores indicate a shallower lake and marshy environments. Alternatively, the same trend may also indicate a transition from deepwater conditions to marsh environments that is not necessarily related to lake-level fluctuations but to the development of aquatic vegetation from the littoral zone into the central lake basin. Either way, we consider PCA axis 1 scores as an indicator for lake-level changes for the Arjan wetland (Fig. 3). In this way, we find a similar chironomid inferred hydrological dynamic already observed in Lake Neor (Fig. 5) located in northwestern Iran (Aubert et al. 2017). At this latter site, high wetland moisture indicating more permanent aquatic conditions is observed between 12000 and 11500 years cal BP. The wetland moisture became low between 11500 and 10300 years cal BP (Aubert 
et al. 2017) with the increase in semiterrestrial taxa indicating ephemeral aquatic conditions on the lake margins.

The early Holocene section of our chironomid record shows a drastic fall in lake levels. This suggests a major environmental change in less than 100 years (Figs. 3 and 5); indeed, the Arjan wetland, which was a deep lake during the YD, suddenly transformed into a shallow lake/marsh environment with a welldeveloped aquatic vegetation at the onset of the Holocene from ca. 11600 years (see aquatic pollen increase in Fig. 3). An increase of Procladius spp. is compatible with lower lake levels, since the members of this genus are carnivorous species (Brooks et al. 2007). In fact, in the shrinking lake water bodies, the higher prey concentration may favor the predation regime. Later, a decrease of Polypedilum nubeculosum-type and slight rise of Chironomus plumosus/ anthracinus-type at the very end of our chironomid record suggest a slight increase in lake levels between $10350-10100$ years cal BP. The persistence of other lacustrine littoral taxa, e.g., Psectrocladius psilopterus-type, Dicrotendipes nervosus-type, and Glyptotendipes pallens-type, confirms the presence of a well-established aquatic vegetation, suggesting a relatively shallow lake/marsh environment. This notion is supported by higher total organic content (TOC), higher carbon accumulation rates, and lower $\delta^{13} \mathrm{C}_{\mathrm{TOC}}$ at Lake Neor, northwestern Iran (Sharifi et al. 2015). The appearance of Xenochironomus spp. (Fig. 3) is imperatively associated with freshwater sponge (Pinder and Reiss 1983), also supporting the hypothesis of a lake level increase during this period. Higher annual temperatures could explain the higher organic productivity in the Arjan wetland due to development of aquatic vegetation and its associated fauna (e.g., Dicrotendipes nervosus-type and Glyptotendipes pallens-type) at the very beginning of the Holocene.

\section{Palaeoclimatic implications}

In summary, the dominance of Chironomus plumosus/anthracinustype indicates the presence of a deep and most probably stratified lake during the YD in Dasht-e Arjan. Several hypotheses could explain such a highstand in Arjan during the YD:

(1) The intensity of the Siberian High during the YD was higher compared to the early Holocene (Mayewski et al.1997; Sharifi et al. 2015). This would have pushed the westerlies to the south providing precipitation over the central and southern Zagros (Sharifi et al. 2018). However, YD pollen assemblages in Arjan are dominated by Amaranthaceae (Chenopodiaceae) with very low relative abundances of Poaceae (Fig. 3), indicating the presence of a typical dry steppe developed under a dry continental climate, excludling this first hypothesis.

(2) Cooler summers during the YD in the Northern Hemisphere could also explain the higher moisture levels in both Arjan and Neor wetlands. Low YD temperatures would have decreased annual lake water evaporation. Evapotranspiration was definitely lower under the generally colder temperatures of the YD in southern Iran. Figure 5 compares the chironomid-based lake-level variations of the Arjan wetland (right) with the NGRIP temperature record (Andersen et al. 2004) and the Ti intensity curve, dust flux concentration curve, and the chironomid-based lake-level variations in Lake Neor in northwestern Iran. It is interesting to note that the lake-level records in both Lake Neor and Arjan follow the same trend, which inversely correlates with the NGRIP temperature record, suggesting the significance of low temperatures in maintaining high lake levels during the YD.

(3) Changes in the seasonality of precipitation, with increased rainfall during the spring/summer months, could also lead to more permanent lake conditions during the summer months (Aubert et al. 2017). Indeed, late-spring precipitation will permit maintaining higher lake levels during summer and greater humidity on lake margins. Nowadays, in the Arjan region, spring precipitation is lower than in northwestern Iran (Djamali et al. 2012) and regional palaeoclimatic records do not suggest increased spring/summer precipitation brought on by stronger monsoon conditions. They show that increased summer precipitation only began around 11000 years cal BP peaking at $10000-6500$ years cal BP and thus postdating the YD (Fleitmann et al. 2007). The hypothesis of a different precipitation seasonality is not satisfactory in explaining the high lake levels at Arjan during the YD.

(4) A further hypothesis is the presence of small glaciers in the catchment area of Arjan due to significant snowfall during the YD. Meltwaters would have maintained high lake levels during the summers. Although no study has so far reported the glacier extensions in the area, the available studies on the last glacial maximum glaciers in central Zagros suggest that the maximum descent of glaciers has been at around $2400 \mathrm{~m}$ elevation during the last glacial maximum (Ebrahimi and Seif 2016). The presence of high mountains exceeding $2600 \mathrm{~m}$ elevation in the lake catchment basin reinforces this hypothesis. Indeed, glaciers at higher elevations could lead to year-round inflow or at least summer inflow as they melt. This would be a distinct difference from Holocene conditions and would not necessitate a change in rainfall seasonality but would change inflow seasonality. It may also explain why the lake levels fall after the transition to the Holocene, when all glaciers had already melted. A glaciogeomorphological survey to attest the evidence of glacier extension in the Arjan area would be helpful to investigate this. We therefore propose that a combination of lower evaporation due to lower annual temperatures, still significant precipitation due to the occasional penetration of southward-pushed westerlies into the southern Zagros (see Sharifi et al. 2018), and continuous glacier melting in the vicinity of the wetland could explain the high lake levels of Arjan during the YD.

(5) Finally, the hydroclimatic processes may not have been the only factor controlling the lake-level changes in Dasht-e Arjan. The complex karstic network of sinkholes in the southern part of the wetland basin could also have played a role in water-level fluctuations. Today, during the highstands, lake water is discharged through these karstic underground galleries preventing the lake level from exceeding a certain altitude corresponding to the sinkhole system in the southeast corner of the basin. The development of this karstic system and its connectivity to adjacent basins (e.g., Lake Parishan basin) possibly accelerated at the beginning of the Holocene. If such a hypothesis is correct, it can be proposed that the early Holocene lake levels would have been much higher if this karstic system had not developed. Highresolution lake-level fluctuations at Lake Parishan during the YD - early Holocene may help to test this hypothesis, e.g., by the detection of a synchronicity between the lake-level fall in Arjan and a lake-level rise in Parishan.

Whatever the case, the YD lake highstand in Arjan adds to the complex hydrological history of the Middle East at the late glacial - early Holocene transition. The hydrological history of each lake basin should be studied by taking into consideration a number of different factors of which climatic change constitutes just one component. For instance, comparing the hydrological evolution of two lake systems in central Anatolia, both located in the same climatic context and most probably experiencing the same hydroclimatic history, shows contrasting trends suggesting that climate was not the only factor controlling lake-level changes. Site-specific factors should also be taken into account when interpreting multiproxy lake-level reconstructions (Roberts et al. 2016).

The Dasht-e Arjan wetland is located in a different climatic context compared to Anatolia and Europe from which numerous lake-level reconstructions are available. Moreover, it would have possibly experienced a different climatic history due to its proximity to the monsoonal zone of southern Asia. It is not thus surprising that it presents a different late glacial-Holocene hydrological evolution when compared to the eastern Mediterranean and Central Asia. Furthermore, as suggested by Roberts et al. (2016), more than one lake record is required to disentangle the 
changes related to climate change from those related to lake ontogeny. Before a general conclusion on lake hydrological changes in southern Zagros can be drawn, other lake records should thus be established and compared and contrasted with that of Arjan.

Southwest Asia shows a more complex hydroclimatic history compared to Europe, best exemplified by the "early Holocene precipitation paradox". Indeed, the geochemical and pollen proxies suggest that different hydrological regimes dominated during the early Holocene. While geochemical data suggest generally higher effective moisture, the pollen records indicate a limited expansion of deciduous forest and thus generally drier conditions. A number of hypotheses have been evoked by different scholars to explain this "paradox" including a different precipitation seasonality in the early compared to the late Holocene, a strong early human impact on forest and steppe forest ecosystems, or a mixture of both (e.g., Stevens et al. 2001; Roberts 2002; Jones and Roberts 2008; Djamali et al. 2010). Part of such conflicting interpretations stems from the fact that the current interpretations are mainly based only on pollen and isotopic proxies. The new palaeohydrological indicators (fossil chironomid assemblages) presented in this study furnish additional data on lakelevel changes and can help in explaining the hydrological paradoxes outlined above. The sensitivity of proxy records to local versus regional climate variabilities also needs to be investigated to supplement the high potential of chironomids, which may reflect changes in climate and hydrology at the local scale. The capacity of chironomid-based lake-level reconstructions to detect high-frequency events during the Holocene should therefore be evaluated in future palaeolimnological investigations.

\section{Conclusions}

The palaeoecological analysis of subfossil chironomid head capsules revealed a major change in the hydrology of the Dasht-e Arjan wetland at the transition of the YD to the onset of the Holocene. In the absence of geochemical proxies from the studied sediment core, the chironomid data helped to reconcile the palaeohydrology of this low-latitude wetland situated in the southern Zagros Mountains. In the Zagros and adjacent highlands, although annual precipitation decreased in a similar manner as the rest of the Northern Hemisphere, the hydrological consequences of lower annual temperatures appear to have maintained higher amounts of water in the wetlands. During the YD, the possible contribution of meltwater from local glaciers to Arjan wetland hydrology shows the necessity to probe the late Quaternary history of glaciers in the Zagros Mountains. At present, it is unclear if such glaciers provided significant water resources during the late glacial period. More late glacial records are still required to understand the spatial patterns of hydrological change in the late Pleistocene - Holocene transition before a regional picture of the hydroclimatic mechanisms driving these changes can be drawn. Although the possible impacts of high effective moisture (high lake levels and aquifers) in the Iranian highlands on the early Neolithic communities was not discussed in the present paper, the data provided in this study and in similar investigations in the Fertile Crescent will help to better understand the possible roles and explanatory mechanisms in the processes of Neolithisation. In particular, providing a palaeoenvironmental/palaeoclimate context for the beginning of plant/animal domestication and the establishment of the first Neolithic sedentary populations is extremely important.

The chironomid-based hydrological reconstruction from Lake Arjan is encouraging. In the future, more quantified data are required for comparisons with regional palaeoclimatic records, e.g., the sea surface temperatures of the Arabian Sea or the speleothem records from southern Asia, northern Iran, Arabia, and Turkey.

\section{Acknowledgements}

We wish to thank the Agence Nationale de Recherche (ANR) as well as the Centre National de la Recherche Scientifique (CNRS) for their financial support of this study under the Franco-German ANR/DFG project "PALEOPERSEPOLIS" (ANR-14-CE35-0026-01) and the Franco-Iranian International Associated Laboratory project called "HAOMA". We also thank Marine Leteurtrois and Gwenaël Magne for their assistance in data acquisition. We wish to thank Professors Neil Roberts (Plymouth University) and Lora Stevens (California State University at Long Beach) for their helpful comments on the interpretation of our data. Finally, we extend our gratitude to two anonymous reviewers for their thoughtful and constructive comments on an earlier version of this paper.

\section{References}

Ammann, B., Birks, H.J.B., Brooks, S.J., Eicher, U., von Grafenstein, U., Hofmann, W. et al. 2000. Quantification of biotic responses to rapid climatic changes around the Younger Dryas - a synthesis. Palaeogeography, Palaeoclimatology, Palaeoecology, 159: 313-347. doi:10.1016/S0031-0182(00)00092-4.

Andersen, K.K., Azuma, N., Barnola, J.M., Bigler, M., Biscaye, P., Caillon, N. et al. 2004. High-resolution record of Northern Hemisphere climate extending into the last interglacial period. Nature, 431(7005): 147-151. doi:10.1038/ nature02805. PMID:15356621.

Aubert, C., Brisset, E., Djamali, M., Sharifi, A., Ponel, P., Gambin, B. et al. 2017. Late glacial and early Holocene hydroclimate variability in northwest Iran (Talesh Mountains) inferred from chironomid and pollen analysis. Journal of Paleolimnology, 58: 151-167. doi:10.1007/s10933-017-9969-8.

Barley, E.M., Walker, I.R., Kurek, J., Cwynar, L.C., Mathewes, R.W., Gajewski, K. et al. 2006. A northwest North American training set: distribution of freshwater midges in relation to air temperature and lake depth. Journal of Paleolimnology, 36: 295-314. doi:10.1007/s10933-006-0014-6.

Blaauw, M. 2010. Methods and code for 'classical' age-modelling of radiocarbon sequences. Quaternary Geochronology, 5: 512-518. doi:10.1016/j.quageo.2010. 01.002 .

Blockley, S.P.E., and Pinhasi, R. 2011. A revised chronology for the adoption of agriculture in the Southern Levant and the role of Lateglacial climatic change. Quaternary Science Reviews, 30: 98-108. doi:10.1016/j.quascirev.2010. 09.021 .

Brodin, Y.W. 1986. The postglacial history of Lake Flarken, southern Sweden, interpreted from subfossil insect remains. Internationale Revue der Gesamten Hydrobiologie und Hydrographie, 71: 371-432. doi:10.1002/iroh.19860710313.

Brooks, S.J., Langdon, P.G., and Heiri, O. 2007. The identification and use of Palaeartic Chironomidae larvae in palaeoecology. Technical Guide No. 10. Quaternary Research Association, London.

Broushaki, F., Thomas, M.G., Link, V., López, S., van Dorp, L., Kirsanow, K. et al. 2016. Early Neolithic genomes from the eastern Fertile Crescent. Science, 353: 499-503. doi:10.1126/science.aaf7943. PMID:27417496.

Chang, J., Zhang, E., Liu, E., and Shulmeister, J. 2017. Summer temperature variability inferred from subfossil chironomid assemblages from the southeast margin of the Qinghai-Tibetan Plateau for the last 5000 years. The Holocene, 27: 1876-1884. doi:10.1177/0959683617708456.

Djamali, M., Akhani, H., Andrieu-Ponel, V., Braconnot, P., Brewer, S., Beaulieu, J.-L. et al. 2010. Indian Summer Monsoon variations could have affected the early-Holocene woodland expansion in the Near East. The Holocene, 20: 813-820. doi:10.1177/0959683610362813.

Djamali, M., Akhani, H., Khoshravesh, R., Andrieu-Ponel, V., Ponel, P., and Brewer, S. 2011. Application of the global bioclimatic classification to Iran: implications for understanding the modern vegetation and biogeography. Ecologia Mediterranea, 37: 91-114.

Djamali, M., Baumel, A., Brewer, S., Jackson, S.T., Kadereit, J.W., López-Vinyallonga, S. et al. 2012. Ecological implications of Cousinia Cass. (Asteraceae) persistence through the last two glacial-interglacial cycles in the continental Middle East for the Irano-Turanian flora. Review of Palaeobotany and Palynology, 172: 10-20. doi:10.1016/j.revpalbo.2012.01.005.

Djamali, M., Gondet, S., Ashjari, J., Marriner, N., Aubert, C., Brisset, E. et al. 2018. Karstic-spring wetlands of the Persepolis Basin, SW Iran: unique sediment archives of Holocene environmental change and human impacts. Canadian Journal of Earth Sciences, 55: 1158-1172. doi:10.1139/cjes-2018-0065.

Ebrahimi, B., and Seif, A. 2016. Equilibrium-line altitudes of Late Quaternary glaciers in the Zardkuh Mountain. Geopersia, 6(2): 299-322. doi:10.22059/ jgeope.2016.58674.

Eggermont, H., Heiri, O., and Verschuren, D. 2006. Fossil Chironomidae (Insecta: Diptera) as quantitative indicators of past salinity in African lakes. Quaternary Science Reviews, 25: 1966-1994. doi:10.1016/j.quascirev.2005.04.011.

Eggermont, H., De Deyne, P., and Verschuren, D. 2007. Spatial variability of chironomid death assemblages in the surface sediments of a fluctuating tropical lake (Lake Naivasha, Kenya). Journal of Paleolimnology, 38: 309-328. doi:10.1007/s10933-006-9075-9.

Engels, S., and Cwynar, L.C. 2011. Changes in fossil chironomid remains along a 
depth gradient: evidence for common faunal thresholds within lakes. Hydrobiologia, 665: 15-38. doi:10.1007/s10750-011-0601-z.

Fleitmann, D., Burns, S.J., Mangini, A., Mudelsee, M., Kramers, J., Villa, I. et al. 2007. Holocene ITCZ and Indian monsoon dynamics recorded in stalagmites from Oman and Yemen (Socotra). Quaternary Science Reviews, 26: 170-188. doi:10.1016/j.quascirev.2006.04.012.

Gandouin, E., Franquet, E., and Van Vliet-Lanoë, B. 2005. Chironomids (Diptera) in river floodplains: their status and potential use for palaeoenvironmental reconstruction purposes. Archiv für Hydrobiologie, 162: 511-534. doi:10.1127| 0003-9136/2005/0162-0511.

Grimm, E.C. (1987) CONISS: A FORTRAN 77 program for stratigraphically constrained cluster analysis by the method of incremental sum of squares. Computers \& Geosciences, 13: 13-35. doi:10.1016/0098-3004(87)90022-7.

Heiri, O., and Lotter, A.F. 2001. Effect of low count sums on quantitative environmental reconstructions: an example using subfossil chironomids. Journal of Paleolimnology, 26: 343-350. doi:10.1023/A:1017568913302.

Heiri, O., Brooks, S.J., Birks, H.J.B., and Lotter, A.F. 2011. A 274-lake calibration dataset and inference model for chironomid-based summer temperature reconstruction in Europe. Quaternary Science Reviews, 30: 3445-3456. doi: 10.1016/j.quascirev.2011.09.006.

Henrikson, L., Olofsson, J.B., and Oscarson, H.G. 1982. The impact of acidification on Chironomidae (Diptera) as indicated by subfossil stratification. Hydrobiologia, 86: 223-229. doi:10.1007/BF00006140.

Hoek, W.Z., Yu, Z.C., and Lowe, J.J. 2008. INTegration of Ice-core, MArine, and TErrestrial records (INTIMATE): refining the record of the last glacialinterglacial transition. Quaternary Science Reviews, 27: 1-5. doi:10.1016/j. quascirev.2007.11.020.

Hosseini, Z., Khaledi, S., and Naderi-Beni, A. 2017. Reconstruction of vegetation and palaeoclimate of Dasht-e Arjan, Fars, during the late Pleistocene and Holocene based on pollen analysis. Journal of Climatological Studies, 27-28: 87-98 (paper in Persian language).

Jones, M.D., and Roberts, C.N. 2008. Interpreting lake isotope records of Holocene environmental change in the Eastern Mediterranean. Quaternary International, 181: 32-38. doi:10.1016/j.quaint.2007.01.012.

Juggins, S. 2007. C2 Version 1.5 User guide. Software for ecological and palaeoecological data analysis and visualisation. NewcastleUniversity, Newcastle upon Tyne, U.K.

Juggins, S. 2017. rioja: analysis of quaternary science data. R package version 0.9-15.1. Available from http://cran.r-project.org/package=rioja.

Langdon, P.G., Ruiz, Z., Wynne, S., Sayer, C.D., and Davidson, T.A. 2010. Ecological influences on larval chironomid communities in shallow lakes: implications for palaeolimnological interpretations. Freshwater Biology, 55: 531-545. doi:10. 1111/j.1365-2427.2009.02345.x.

Lowe, J.J., and Walker, M.J.C. 1997. Reconstructing Quaternary environments. 2 ed. Routledge, Harlow.

Luoto, T.P., Ojala, A.E.K., Arppe, L., Brooks, S.J., Kurki, E., Oksman, M. et al. 2018. Synchronized proxy-based temperature reconstructions reveal mid- to late Holocene climate oscillations in High Arctic Svalbard. Journal of Quaternary Science, 33: 93-99. doi:10.1002/jqs.3001.

Matthews, R., and Fazeli Nashli, H. 2013. The neolithisation of Iran. Oxbow Books, Oxford (Royaume Uni).

Mayewski, P.A., Meeker, L.D., Twickler, M.S., Whitlow, S., Yang, Q., Lyons, W.B. et al. 1997. Major features and forcing of high-atitude northern hemisphere atmospheric circulation using a 110,000-year-long glaciochemical series. Journal of Geophysical Research, 102: 26345-26366. doi:10.1029/96JC03365.

Milanovic, P., and Aghili, B. 1990. Hydrogeological characteristics and groundwater mismanagement of Kazerun karstic aquifer, Zagros, Iran. Hydrogeological Processes in Karst Terranes, 10: 163-171.
Pinder, L.C.V., and Reiss, F. 1983. The larvae of Chironominae (Diptera: Chironomidae) of the Holartic region. Keys and diagnoses. Entomologica Scandinavica Supplement, 19(Suppl.): 293-435.

R Core Team. 2012. R: a language and environment for statistical computing. R Foundation for Statistical Computing, Vienna, Austria.

Rasmussen, S.O., Andersen, K.K., Svensson, A.M., Steffensen, J.P., Vinther, B.M., Clausen, H.B. et al. 2006. A new Greenland ice core chronology for the last glacial termination. Journal of Geophysical Research, 111. doi:10.1029/ 2005JD006079.

Reimer, P.J., Bard, E., Bayliss, A., Beck, J.W., Blackwell, P.G., Ramsey, C.B. et al. 2013. IntCal13 and Marine13 radiocarbon age calibration curves $0-50,000$ years cal BP. Radiocarbon, 55: 1869-1887. doi:10.2458/azu_js_rc.55.16947.

Riehl, S., Zeidi, M., and Conard, N.J. 2013. Emergence of agriculture in the foothills of the Zagros Mountains of Iran. Science, 341: 65-67. doi:10.1126/science. 1236743. PMID:23828939.

Roberts, N. 2002. Did prehistoric landscape management retard the post-glacial spread of woodland in Southwest Asia? Antiquity, 76: 1002-1010. doi:10.1017| S0003598X0009181X.

Roberts, N., Allcock, S.L., Arnaud, F., Dean, J.R., Eastwood, W.J., Jones, M.D. et al. 2016. A tale of two lakes: a multi-proxy comparison of Lateglacial and Holocene environmental change in Cappadocia, Turkey. Journal of Quaternary Science, 31: 348-362. doi:10.1002/jqs.2852.

Seyrafian, A., Vaziri-Moghaddam, H., Arzani, N., and Taheri, A. 2011. Facies analysis of the Asmari Formation in central and north-central Zagros basin, southwest Iran: biostratigraphy, paleoecology and diagenesis. Revista Mexicana de Ciencias Geológicas, 28(3): 439-458.

Sharifi, A., Pourmand, A., Canuel, E.A., Ferer-Tyler, E., Peterson, L.C., Aichner, B. et al. 2015. Abrupt climate variability since the last deglaciation based on a high-resolution, multi-proxy peat record from NW Iran: the hand that rocked the cradle of civilization? Quaternary Science Reviews, 123: 215-230. doi:10. 1016/j.quascirev.2015.07.006.

Sharifi, A., Murphy, L.N., Pourmand, A., Clement, A.C., Canuel, E.A., Naderi, Beni, A. et al. 2018. Early-Holocene greening of the Afro-Asian dust belt changed sources of mineral dust in West Asia. Earth and Planetary Science Letters, 481: 30-40. doi:10.1016/j.epsl.2017.10.001.

Stevens, L.R., Wright, H.E., Jr., and Ito, E. 2001. Proposed changes in seasonality of climate during the Lateglacial and Holocene at Lake Zeribar, Iran. The Holocene, 11: 747-755. doi:10.1191/09596830195762.

Stevens, L.R., Ito, E., Schwalb, A., and Wright, H.E., Jr. 2006. Timing of atmospheric precipitation in the Zagros Mountains inferred from a multi-proxy record from Lake Mirabad, Iran. Quaternary Research, 66: 494-500. doi:10. 1016/j.yqres.2006.06.008.

Verneaux, V., and Aleya, L. 1998. Bathymetric distributions of chironomid communities in ten French lakes: implications on lake classification. Fundamental and Applied Limnology, 142: 209-228. doi:10.1127/archiv-hydrobiol/142/ $1998 / 209$

Wang, H., Chen, J., Zhang, S., Zhang, D.D., Wang, Z., Xu, Q. et al. 2018. A chironomid-based record of temperature variability during the past 4000 years in northern China and its possible societal implications. Climate of the Past, 14: 383-396. doi:10.5194/cp-14-383-2018.

Willcox, G. 2012. The beginnings of cereal cultivation and domestication in Southwest Asia. In A companion to the archaeology of the ancient Near East. Edited by D. Potts. Wiley Blackwell Malden, Oxford.

Zhang, E., Jones, R., Bedford, A., Langdon, P., and Tang, H. 2007. A chironomidbased salinity inference model from lakes on the Tibetan Plateau. Journal of Paleolimnology, 38: 477-491. doi:10.1007/s10933-006-9080-z. 